\title{
Effects Of Drought Stress on Germination in Fourteen Provenances of Pinus Brutia Ten. Seeds in Turkey
}

\author{
Hakan Şevik $^{1^{*}}$, Nihat Ertürk ${ }^{2}$ \\ ${ }^{1}$ Faculty of Engineering and Architecture, Kastamonu University, 37100 Kastamonu, Turkey \\ ${ }^{2}$ Institute of Science and Technology, Kastamonu University 37150 Kastamonu, Turkey
}

\section{A R T I C L E IN F O}

Article history:

Received 13 June 2014

Accepted 22 October 2014

Available online, ISSN: 2148-127X

Keywords:

PEG

Pinus brutia Ten.

Drougth Stress

Seed Germination

Germination

${ }^{*}$ Corresponding Author:

E-mail: hakansevik@gmail.com

\section{A B S T R A C T}

Pinus brutia Ten., Red pine, known to be tough drought resistant pine specie, could effectively be used for afforestation of disturbed areas. It is of great interest for the afforestation in arid zones. Appropriate seed sources for the specific areas guarantees reforestation success. Away from its native areas Pinus brutia Ten. is planted for its ornamental value and timber production purposes. Selection of drought resistant provenances can very well increase the survival success. In this study, the effects of water potential on germination were studied in fourteen provenances of Pinus brutia Ten. from Turkey. Water potentials between 0 and -8 bars were obtained using polyethylene glycol 6000 (PEG-6000) solutions. Seeds were kept for 35 day at $20 \pm 0.5^{\circ} \mathrm{C}$. A decrease in water potential produced a marked reduction in germination percentage and germination value. As a result, significant variations between the provenances were found. It was determined that, under a -8 bar water stress, Isparta-Bucak and Mersin-Silifke, respectively corresponding to $58 \%$ and $57 \%$ of the control group, were the least water stress affected provenances.

\section{Introduction}

The plants used in planting studies in rural-arid areas, where ecological problems are plenty can be protected from drought effects by the addition of organic materials, watering and consistent care. The plants suffer later wither because these applications cannot be performed in many areas, consequently planting works fail because no good growth can be attained. Recently, water matter and aridity have started becoming a big threat for the plants of problematic areas due to global warming and significant air temperature increases in the summer. One of the solutions of these problems is to use plants surviving on minute amounts of water (Pulatkan and Var, 2010). Plant to be utilized in landscape projects are expected to withstand drought, this objective is the most important criteria affecting the plants selection in such studies (Y1lmaz and Yilmaz, 2009).

Utilization of natural plant species in landscape projects require effective watering as well as plant medicine use and fertilization, so maintenance costs can drastically be reduced. Furthermore, the natural species acclimatizing the environmental conditions can endure plant diseases and pests better, so along with economical benefits, ecological benefits in terms of environment and nature protection can be acquired. Besides, consumer demands in recent years are turning to the selection of natural species (Atik and Karagüzel, 2007). Thus, such species must be prioritized in landscape projects.

Pinus brutia Ten. is well adapted to the Mediterranean type climate and spreads abundantly throughout the Eastern Mediterranean area (Quezel, 1979; Panetsos, 1981). It grows mainly from sea level up to $1400 \mathrm{~m}$ in the Mediterranean part of Turkey and sparsely distributed along the Black Sea coastal area from sea level up to 600 $\mathrm{m}$ (Tilki and Dirik, 2007).Pinus brutia Ten usually grows in pure stands and occupies 3.6 million ha of forest land, which constitutes about $20 \%$ of the total forest areas in Turkey; it is valuable for its timber products as well as for soil stabilization and wildlife habitats (Neyisci, 1987; Boydak, 2004; Tilki and Dirik, 2007).

Pinus brutia Ten. is also well suited to landscape projects. It is extensively used in school yards (Şişman and Gültürk, 2011), in parks (Ekici and Sarıbaş, 2006; Acar et al., 2007), in amelioration works of abandoned mining sites (Akpınar, 2005) and is recommended in such projects.

Pinus brutia Ten. can be used for afforestation of degraded areas because of its drought resistance. The use of appropriate seed sources for the specific areas affects reforestation success. Thus, the investigation of the adaptive mechanisms regarding seed germination and 
seedling establishment are of great importance to conservation and regeneration of the Mediterranean pine ecosystems (Tilki and Dirik, 2007).

Away from its native areas, Pinus brutia Ten. is planted for ornament and timber in the Mediterranean south to Israel, west to Spain and east to Pakistan, and in Australia, New Zealand, South Africa, California and Arizona. It is of great interest for the afforestation of arid zones (Frankis, 2004).

That the endurance of the very same specie towards drought differs drastically among provenances is indicated in many studies. In order to increase the success of afforestation in dry regions, it is very imperative to use the most drought resistant provenances of such species.

Various methods are utilized to determine the drought tolerance of different species and provenances, one of which is to apply different concentrations of PEG on seeds. (Afzali et al., 2006; Hamayun et al., 2010; Shafeeq, et al., 2006; Ahmad et al., 2009; Mujtaba et al., 2007). Polyethylene (PEG) induced water stress has successfully been used to screen drought tolerance in many plant species (Raziuddin et al., 2010).

Soil water supply is an important environmental factor controlling seed germination (Kramer and Kozlowski, 1979). If the water potential is reduced, seed germination will be delayed or prevented depending on the extent of its reduction (Hegarty, 1978). One technique for studying the effect of water stress on germination is to simulate stress conditions using artificial solutions to provide variable water potentials (Larson and Shubert, 1969; Sharma, 1973; Falusi et al., 1983; Boydak et al., 2003)

In this study, the effects of water stress were examined in 14 provenances of Pinus brutia Ten. using PEG solutions with water potentials ranging from 0 to -8 bars. The purpose of this study was to evaluate the influence of water stress on germination and to determine whether there was a significant intraspecific variation in drought tolerance between provenances of Pinus brutia Ten. seeds from different provenances.

\section{Materials and Methods}

Seeds were collected from 14 natural stands of Pinus brutia Ten. by the Forest Trees and Seeds Improvement Division, Ministry of Forestry, Turkey. The seeds were extracted, cleaned and stored in a dark and cool place at $4^{\circ} \mathrm{C}$ until used. The locations of seed stands are shown in Table 1.

Before the germination tests, damaged and insect infected seeds were discarded, and the empty ones were eliminated using the floating method in distilled water. The water potential of the germination substrates $(0,-2$, $4,-6$ and -8 bars) was determined using PEG-6000 solution, prepared as described by Michel and Kaufman (1973).

Germination tests were performed in $11 \mathrm{~cm}$ diameter glass petri dishes on two layers of filter paper saturated with water solutions. Four 50 seed replicates for each lot and for each experimental condition were used, culminating to a total of 280 replicates (4 replicates [each has 50 seeds] $* 5$ water potential levels $* 14$ provenances $=$
280). Filter papers and solutions were changed every 3 day in order to keep the water potential steady during the whole test period.

Experiments were carried out in a temperature controlled growth chamber at $20 \pm 0.5^{\circ} \mathrm{C}$. Germination counts were performed daily for 35 days and germination was considered to have occurred if a radicle protruded 2 $\mathrm{mm}$ from the seed coat (Boydak et al., 2003). Seeds with abnormal radicles were excluded from the germination counts.

Cumulative (germinated seed/total germination percentage) germination percentage, (GP\%) was evaluated daily and the final value was obtained after 35 days. Then all cumulative germination percentages of the provenances at every stress level were transformed to relative cumulative germination percentages by considering the control germinations ( 0 bars) to be 100 . Data were subjected to multi-way analysis of variance and Duncan test.

Mean Germination values $(\mathrm{GV})$ were also calculated by the formula of "Djavanshir and Pourbeik" (1976) because it is believed to give a more reliable estimate of subsequent survival for the genus Pinus. Thus, GV was computed as follows: $\mathrm{GV}=(\mathrm{SDGS} / \mathrm{N}) \times \mathrm{GP} \times 10$, where DGS is daily germination speed, which is computed by dividing the cumulative germination percentage by the number of days since the beginning of the test. $\mathrm{N}$ is the number of DGS calculated during the test (Boydak et al., 2003).

Table 1 The locations of seed stands

\begin{tabular}{c|ccc}
\hline Pop. No & Region & Local Region & Altitude $(\mathrm{m})$ \\
\hline 1 & Muğla & Marmaris & 60 \\
2 & Mersin & Silifke & 100 \\
3 & Mersin & Bozyazı & 250 \\
4 & Isparta & Bucak & 350 \\
5 & K.Maraş & Antakya & 385 \\
6 & Mersin & Anamur & 500 \\
7 & Mersin & Bozyazı & 500 \\
8 & Mersin & Gülnar & 650 \\
9 & Antalya & Gündoğmuş & 650 \\
10 & Isparta & Sütçüler & 650 \\
11 & Adana & Pos & 735 \\
12 & Denizli & Acipayam & 850 \\
13 & Mersin & Erdemli & 900 \\
14 & Mersin & Anamur & 925 \\
\hline
\end{tabular}

\section{Results}

Analysis of variance showed highly significant differences among both provenances and water potentials (Table 2).

According to Table 2, there were significant differences among provenances and applications for all characters (Germination Percentage, Relative Germination Percentage and Germination Value). Average values and results of Duncan test for applications and provenances are shown in Table 3 for germination percentage. 
Table 2 Results of variance analysis

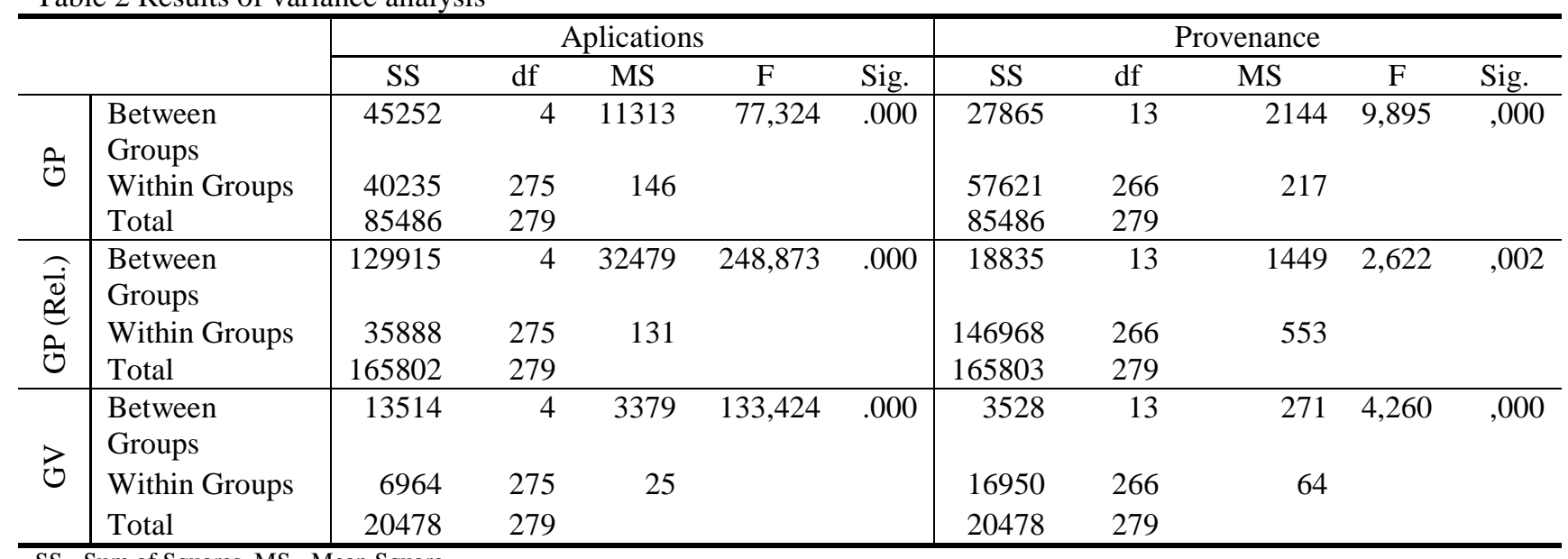

$\mathrm{SS}=$ Sum of Squares, $\mathrm{MS}=$ Mean Square

Table 3 Effects of water potential on germination percentage of Pinus brutia Ten. seeds from 14 provenances.

\begin{tabular}{|c|c|c|c|c|c|c|}
\hline \multirow{2}{*}{ Provenance } & \multicolumn{6}{|c|}{ Water potential (bars) } \\
\hline & 0 & 2 & 4 & 6 & 8 & Average \\
\hline 1 & 44 & 42.5 & 35 & 30.5 & 18.5 & $34.1 \mathrm{ef}$ \\
\hline 2 & 80 & 65.5 & 60 & 50.5 & 45.5 & $60.3 \mathrm{ab}$ \\
\hline 3 & 68 & 53 & 48.5 & 40 & 33 & $48.5 \mathrm{~cd}$ \\
\hline 4 & 76 & 80 & 59 & 48.5 & 44 & $61.5 \mathrm{a}$ \\
\hline 5 & 49 & 36.5 & 24.5 & 16 & 11.5 & $27.5 \mathrm{f}$ \\
\hline 6 & 67 & 36.5 & 34 & 25.5 & 19.5 & 36.5 ef \\
\hline 7 & 54 & 42 & 42 & 32.5 & 22 & $38.5 \mathrm{e}$ \\
\hline 8 & 64 & 53 & 37.5 & 29 & 24.5 & $41.6 \mathrm{de}$ \\
\hline 9 & 58 & 41 & 38.5 & 34 & 9 & 36.1 ef \\
\hline 10 & 76 & 56.5 & 53.5 & 47 & 26 & $51.8 \mathrm{bc}$ \\
\hline 11 & 44 & 38.5 & 36.5 & 25 & 16.5 & 32.1 ef \\
\hline 12 & 45 & 40 & 36 & 24.5 & 21 & $33.3 \mathrm{ef}$ \\
\hline 13 & 62 & 45.5 & 35 & 24.5 & 21 & 37.6 ef \\
\hline 14 & 52 & 63.5 & 47.5 & 26 & 18.5 & $41.5 \mathrm{de}$ \\
\hline Average & $59.9 \mathrm{a}$ & $49.6 \mathrm{~b}$ & $42 \mathrm{c}$ & $32.4 \mathrm{~d}$ & $23.6 \mathrm{e}$ & \\
\hline
\end{tabular}

As followed through Table 3, the germination percentage is decreased with the increasing water stress and it, being around $59.9 \%$ in control group, decreases to $23.6 \%$ at a -8 bar water stress. As for the provenance point of view, it was observed that number "4" had the highest germination percentage of $61.5 \%$, while number " 5 " had the least germination percentage of $27.5 \%$. However, as opposed to average germination percentage, the purpose of the study is to determine the hardiest drought resistant provenance; the amount of water stress related germination reduction becomes important. When the control group is taken into account as $100 \%$, the values attained in germination percentage and the results of Duncan test applied to such values can be followed through Table 4.

Based on the findings of Table 4, water germination percentage reduces depending upon the stress level and at around -8 bar water stress, it gets down to about $38.7 \%$ of the total germination percentage. As for provenances, the most intensive reduction occurred in the provenance, "9". In this provenance also, at around -8 bar water stress, it gets down to about $16 \%$ of the total germination percentage; the provenances, " 4 " and " 6 " follow this one with $23 \%$ and $29 \%$, respectively.

Under a -8 bar water stress, Isparta-Bucak, provenance "4", and Mersin-Silifke, provenance " 2 ", respectively corresponding to $58 \%$ and $57 \%$ of the control group, were the least water stress affected provenances. Although under a -2 bar water stress, in provenances " 4 " and " 14 ", the germination percentage registered higher compared to that of the control group, this is thought to be an exception. In general, the more the water stress increases, the less the germination percentage gets.

The effects of water potential on germination value (GV, \%) of seeds from 14 provenances of Pinus brutia Ten. are shown in Table 5.

As examined through Table 5, on the basis of water stress, while the germination value is about 21.6; as the water stress increases, this particular value reduces and, at around -6 bar water stress, gets down to 3.7, and at around -8 bar water stress, gets further down to 2.3 . According to the results of Duncan test, while the levels of -6 and -8 bar are placed in the same homogenous group, the rest is placed in different groups. On the other hand, when the 
provenances are taken into account, the provenance " 4 ", being 34.7 in control group and dropping to 15.7 at -8 bar and the provenance " 2 " being 35.7 in control group and dropping to 15.2 at -8 bar, could be regarded as the most water stress tolerant provenances. Besides, the provenance "9", being 22.4 in GV control group and dropping to 0.25 at -8 bar and the provenance " 5 " being 12.5 in control group and dropping to 0.45 at -8 bar, are determined as the least water stress tolerant provenances.

\section{Discussion}

Drought tolerance screening related to Polyethylene (PEG) induced water stress has successfully been performed in many agricultural plant species such as Matricaria chamomilla (Afzali et al., 2006), Soybean (Hamayun et al., 2010), Helianthus annuus (Ahmad et al., 2009), Triticum aestivum (Raziuddin et al., 2010; Mujtaba et al., 2007; Shafeeq, et al., 2006), sugarcane (Errabi et al., 2006; Errabi et al., 2007), rice (Ahmad et al., 2007; Liu et al., 2007; Lefèvre et al., 2001), cowpea (Costa et al., 2007), alfalfa (Safarnejad, 2008), lentil (Yupsanis et al., 2001), maize (Ashraf et al., 2007) and halophyte species i.e. Sevium portulacastrum (Slama et al., 2007), Cantaurea ragusina (Radić et al., 2005; Radić et al., 2006), Suaeda salsa and Kalanchoe claigremontiana (Kefu et al., 2003).

In this study, the seeds of Pinus brutia Ten. from 14 regions were germinated under water stress. Decreasing the water potential in the substrate decreased germination, indicating that water stress inhibits germination. Germination percentage was adversely affected when moisture stress increased, while it was reduced at -8 bars by more than half. This result agrees well with the findings of Boydak et al., (2003) and Falusi and Calamassi (1982). Similar trends have also been observed in some other conifer species; lowering the water potential to -8 bars reduced the germination of Pinus nigra (Buyurukcu, 2011), Pinus pinaster (Falleri, 1994), Pinus contorta and Picea engelmanii by approximately 50\% (Kaufman \& Eckard, 1977). Falusi et al. (1983) observed in Pinus halepensis that a reduction of the water potential of the germination substrate even to -2 bars lowers germination percentages considerably, while at -8 bars germination was lowered to approximately $25 \%$.

In contrast, Thanos and Skordilis (1987) reported that Pinus brutia Ten. seeds exhibited water inhibition of germination at values lower than -10 bars, and the absolute values of the water potential required for $50 \%$ inhibition of germination in Pinus halepensis were between -14.6 and -19.5 bars at both $15^{\circ} \mathrm{C}$ and $20^{\circ} \mathrm{C}$. The results of this research support the idea that Pinus brutia Ten. is well adapted to the Mediterranean-type climate and is a drought-resistance species with respect to several physiological characteristics (Boydak et al., 2003).

In another study, water priming with aerated solutions of polyethylene glycol improved both final germination and the speed of germination in Pinus brutia Ten. (Dirik et al., 1999). The response of germination to water stress differed among the six provenances. This intraspecific variation agrees with the experimental data reported for Pinus brutia Ten. (Calamassi et al., 1980; Falusi and Calamassi, 1982), Pinus nigra (Buyurukcu, 2011; Calikoglu, 2002), Pinus elderica and Pinus halepensis (Calamassi et al., 1980; Falusi et al., 1983; Thanos and Skordilis, 1987), Pinus sylvestris (Tilki, 2005), Pinus taeda (Dunalp and Barnett, 1984) and Pinus ponderosa (Djavanshir and Reid, 1975).

\section{Acknowledgement}

In this study, Institute of Science in Forestry Engineering Department is belong to Master's Degree in Kastamonu University.

Table 4 Effects of water potential on relative cumulative germination percentage of Pinus brutia Ten. seeds from 14 provenances.

\begin{tabular}{|c|c|c|c|c|c|c|}
\hline \multirow{2}{*}{ Provenance } & \multicolumn{6}{|c|}{ Water potential (bars) } \\
\hline & 0 & 2 & 4 & 6 & 8 & Average \\
\hline 1 & 100 & 97 & 80 & 69 & 42 & $77.6 \mathrm{ab}$ \\
\hline 2 & 100 & 82 & 75 & 63 & 57 & $75.4 \mathrm{ab}$ \\
\hline 3 & 100 & 78 & 71 & 59 & 49 & $71.4 \mathrm{abc}$ \\
\hline 4 & 100 & 105 & 78 & 64 & 58 & $81.0 \mathrm{a}$ \\
\hline 5 & 100 & 74 & 50 & 33 & 23 & $56.0 \mathrm{c}$ \\
\hline 6 & 100 & 54 & 51 & 38 & 29 & $54.4 \mathrm{c}$ \\
\hline 7 & 100 & 78 & 78 & 60 & 41 & $71.4 \mathrm{abc}$ \\
\hline 8 & 100 & 83 & 59 & 45 & 38 & $65.0 \mathrm{abc}$ \\
\hline 9 & 100 & 71 & 66 & 59 & 16 & $62.4 \mathrm{bc}$ \\
\hline 10 & 100 & 74 & 70 & 62 & 34 & $68.0 \mathrm{abc}$ \\
\hline 11 & 100 & 88 & 83 & 57 & 38 & $73.2 \mathrm{ab}$ \\
\hline 12 & 100 & 89 & 80 & 54 & 47 & $74.0 \mathrm{ab}$ \\
\hline 13 & 100 & 73 & 56 & 40 & 34 & $60.6 \mathrm{bc}$ \\
\hline 14 & 100 & 122 & 91 & 50 & 36 & $79.8 \mathrm{a}$ \\
\hline Average & $100 \mathrm{a}$ & $83.4 \mathrm{~b}$ & $70.6 \mathrm{c}$ & $53.8 \mathrm{~d}$ & $38.7 \mathrm{e}$ & \\
\hline
\end{tabular}


Table 5 Effects of water potential on germination value (GV, \%) of seeds from 14 provenances of Pinus brutia Ten.

\begin{tabular}{|c|c|c|c|c|c|c|}
\hline \multirow{2}{*}{ Provenance } & \multicolumn{6}{|c|}{ Water potential (bars) } \\
\hline & 0 & 2 & 4 & 6 & 8 & Average \\
\hline 1 & 10.5 & 4.55 & 3.8 & 2.6 & 0.9 & $4.5 \mathrm{de}$ \\
\hline 2 & 35.7 & 12.95 & 11.4 & 7.55 & 7.15 & $15.2 \mathrm{ab}$ \\
\hline 3 & 26.6 & 8.1 & 6.95 & 4.35 & 3.85 & $10.0 \mathrm{bcd}$ \\
\hline 4 & 34.7 & 19.6 & 9.85 & 7 & 7.15 & $15.7 \mathrm{a}$ \\
\hline 5 & 12.5 & 3.8 & 1.9 & 0.8 & 0.45 & $3.9 \mathrm{e}$ \\
\hline 6 & 28.5 & 3.35 & 3.25 & 1.6 & 1.05 & $7.6 \mathrm{cde}$ \\
\hline 7 & 16.8 & 4.95 & 7.2 & 3.3 & 2.25 & 6.9 cde \\
\hline 8 & 27.9 & 8.65 & 5 & 3.05 & 1.35 & $9.2 \mathrm{cde}$ \\
\hline 9 & 22.4 & 5.2 & 4 & 3.35 & 0.25 & 7.0 cde \\
\hline 10 & 32.3 & 8.1 & 7.9 & 7.45 & 2.3 & $11.6 \mathrm{abc}$ \\
\hline 11 & 11.2 & 4.25 & 4.15 & 2.55 & 1.05 & $4.6 \mathrm{de}$ \\
\hline 12 & 11.7 & 10.8 & 4.3 & 2.3 & 2.05 & $6.2 \mathrm{cde}$ \\
\hline 13 & 19.9 & 5.25 & 2.7 & 1.85 & 1.2 & $6.2 \mathrm{cde}$ \\
\hline 14 & 12 & 13.8 & 8.25 & 3.75 & 1.45 & 7.9 cde \\
\hline Average & $21.6 \mathrm{a}$ & $8.1 \mathrm{~b}$ & $5.8 \mathrm{c}$ & $3.7 \mathrm{~d}$ & $2.3 \mathrm{~d}$ & \\
\hline
\end{tabular}

\section{References}

Acar C, Acar H, Eroğlu E. 2007. Evaluation of ornamental plant resources to urban biodiversity and cultural changing: A case study of residential landscapes in Trabzon city (Turkey), Building and Environment 42: 218-229

Afzali SF, Hajabbasi MA, Shariatmadari H, Razmjoo K, Khoshgoftarmanesh AH. 2006. Comparative adverse effects of PEG- or $\mathrm{NaCl}$ - Induced osmotic stress on germination and early Seedling growth of a potential medicinal Plant Matricaria chamomill, Pak. J. Bot., 38: 1709-1714.

Ahmad MSA, Javed F, Ashraf M. 2007. Iso-osmotic effect of $\mathrm{NaCl}$ and PEG on growth, cations and free proline accumulation in callus tissue of two indica rice (Oryza sativa L.) genotypes. Plant Growth Regul., 53: 53-63.

Ahmad S, Ahmad R, Ashraf MY, Ashraf M, Waraich EA. 2009. Sunflower (Helianthus annuus 1.) Response to drought stress at germination and seedling growth stages, Pak. J. Bot., 41: 647-654.

Akpınar N., 2005. Madencilik Faaliyetleri Sonrası Onarım Çalışmalarında Bitkilendirme Süreci, Madencilik ve Çevre Sempozyumu, 5-6 Mayıs 2005, Ankara, 159-164

Ashraf M, Nawazish S, Athar H. 2007. Are chlorophyll fluorescence and photosynthetic capacity potential physiological determinants of drought tolerant in maize (Zea mays L.). Pak. J. Bot., 39: 1123-1131.

Atik M, Karagüzel O. 2007. Peyzaj Mimarlığı Uygulamalarında $\mathrm{Su}$ Tasarrufu Olanakları ve Süs Bitkisi Olarak Doğal Türlerin Kullanım Önceliği, Akdeniz Üniversitesi, Ziraat Fakültesi, Peyzaj Mimarlığı Bölümü, Antalya

Boydak M, Dirik H, Tilki F, Calikoglu M. 2003. Effects of water stress on germination in six provenances of Pinus brutia seeds from different bioclimatic zones in Turkey. Turk. J. Agric. For., 27: 91-97.

Boydak M. 2004. Silvicultural characteristics and natural regeneration of Pinus brutia Ten. A review. Plant Ecol., 171: 153-163.

Buyurukcu S. 2011. Clonal variation as to the reaction against to drought in the Hanönü-Günlüburun black pine (Pinus nigra Arnold ssp.pallasiana Lamb. Holmboe ) seed orchard, M.Sc.Thesis, Kastamonu University, Graduate School of Natural and Applied Sciences Department of Forest Engineering, $61 \mathrm{p}$.

Calamassi R, Falusi M, Tocci A. 1980. Variazione geografica e resistenza a stress idrici in semi di Pinus halepensis Mill.
Pinus brutia Ten. and Pinus elderica Medw, Annali dell'Istituto Sperimentale per la Selvicoltura XI: 195-230.

Costa JH, Jolivet Y, Hasenfratz-Sauder MP, Orellano EG, Lima MGS, Dizengremel P, de Melo DF. 2007. Alternative oxidase regulation in roots of Vigna unguiculata cultivars differing in drought/salt tolerance. J. Plant Physiol., 164: 718-727

Çalıkoğlu M. 2002. Anadolu Karaçamı (Pinus nigra Arnold ssp. Pallasiana Lamb.Holmboe) Orijinlerinin Kuraklıklara Karşı Reaksiyonlarını Ekofizyolojik Analizi, Doktora tezi, İÜ Fen Bilimleri Enstitüsü, İstanbul.

Dirik H, Çalıkoğlu M, Tilki F. 1999. Effects of osmotic priming on germination of Calabrian pine (Pinus brutia Ten.) seeds, IÜ, Orm. Fak. Derg. Seri A, 49: 75-89.

Djavanshir K, Reid CCP. 1975. Effect of moisture stress on germination and radicle development of Pinus eldarica Medw. And Pinus ponderosa Laws, Canadian Journal of Forest Research 5: 80-83.

Djavanshir K, Pourbeik H. 1976. Germination value- a new formula, Silvae Genetica 25: 79-83.

Dunalp JR, Barnett JP. 1984. Manipulating loblolly pine (Pinus taeda L.) seed germination with simulated moisture and temperature stress. In: Seedling Physiology and Reforestation Success (Eds.: M.L. Duryea and G.N. Brown). Martinus Nijhoff/Dr. W. Junk. Publ., Boston, pp. 61-74.

Ekici B, Sarıbaş M. 2006. A research on the plant material used in landscape design of Bartın province, ZKÜ Bartın Orman Fakültesi Dergisi, 8,9; 1-9.

Errabii T, Gandonou CB, Essalmani H, Abrini J, Idomar M, Senhaji NS. 2006. Growth, proline and ion accumulation in sugarcane callus cultures under drought-induced osmotic stress and its subsequent relief. Afri. J. Biotechnol., 5: 11481493.

Errabii T, Gandonou CB, Essalmani H, Abrini J, Idaomar M, Senhaji NS. 2007. Effect of $\mathrm{NaCl}$ and mannitol induced stress on sugarcane (Saccharum sp.) callus cultures. Acta Physiol. Plant., 29: 95-102.

Falleri E. 1994. Effect of water stress on germination in six provenances of Pinus pinaster Ait, Seed Science and Technology 22: 591-599.

Falusi M, Calamassi R. 1982. Effeti degli stress idrici su germinazione e crescita della radice in cinque provenienze di Pinus brutia Ten. (Effects of moisture stress on 
germination and root growth in provenances of Pinus brutia Ten.), Ann. Acc. It. Sc. For. XXXI: 99118.

Falusi, M., R. Calamassi and A. Tocci. 1983. Sensitivity of seed germination and seedling root growth to moisture stress in four provenances of Pinus halepensis Mill., Silvae Genetica 32: 4-9.

Frankis M. 2004, Pinus brutia, Pinaceae, Curtis's Botanical Magazine, 16: (3), Article first published online: 14 Jan 2004

Hamayun M, Khan SA, Shınwari ZK, Khan A, Ahmad N, Lee IJ. 2010. Effect of polyethylene glycol induced Drought stress on physio-hormonal attributes of soybean, Pak. J. Bot., 42: 977-986,

Hegarty TW. 1978. The physiology of seed hydration and dehydration, and the relation between water stress and control of germination: a review, Plant Cell Environment 1: 101-109.

Kaufmann MR, Eckard AN. 1977. Water potential and temperature effects on germination of Engelmann spruce and Lodgepole pine seeds, Forest Science 23: 27-33.

Kefu Z, Hai F, San Z, Jie S. 2003. Study on the salt and drought tolerance of Suaeda salsa and Kalanchoe claigremontiana under iso-osmotic salt and water stress. Plant Sci. 165: 837844.

Kramer PJ, Kozlowski TT. 1979. Physiology of woody plants. Academic Press, New York, 811 p.

Larson MM, Shubert GN. 1969. Effect of osmotic water stres on germination and initial development of Ponderosa pine seedlings, Forest Science 15: 30-36.

Lefèvre I, Gratia E, Lutts S. 2001. Discrimination between the ionic and osmotic components of salt stress in relation to free polyamine level in rice (Oryza sativa). Plant Sci., 161: 943-952.

Liu SH, Fu BY, Xu HX, Zhu LH, Zhai HQ, Li ZK. 2007. Cell death in response to osmotic and salt stresses in two rice (Oryza sativa L.) ecotypes. Plant Sci., 172: 897-902.

Michel BE, Kaufmann MR. 1973. The osmotic potential of polyethylene glycol 6000, Plant Physiology 51: 914-916.

Mujtaba SM, Ali M, Ashraf MY, Khanzada B, Farhan SM, Shirazi MU, Khan MA, Shereen A, Mumtaz S. 2007. Physiological responses of wheat (Triticum aestivum L.) Genotypes under water stres conditions at seedling stage, Pak. J. Bot., 39: 2575-2579.

Neyisci T. 1987. Kızılcamın Dogal Yayılışı. Muhtelif yayınlar No. 52. Ormancılık Araştırma Enstitusu. Ankara.

Panetsos KP. 1981. Monograph of Pinus halepensis (Mill.) and Pinus brutia (Ten.). Ann. Forest., 9: 39-77.

Pulatkan M, Var M. 2010. The adventages and usage of mycorrhizal plants in forestry and landscape architecture, III. Ulusal Karadeniz Ormanc1lık Kongresi 20-22 May1s 2010 Cilt: IV p: 1431-1438
Quezel P. 1979. La région méditerranéenne française et ses essences forestiéres, signification écologique dans le contexte circumm- méditerranéene Forét Méditerranéenne I: 7-18.

Radić S, Prolić M, Pavlica M, Pevalek-Kozlina B. 2005. Cytogenetic effects of osmotic stress on the root meristem cells of Centaurea ragusina L. Env. Exp. Bot., 54: 213-218.

Radić S, Radić-Stojković M, Pevalek-Kozlina B. 2006. Influence of $\mathrm{NaCl}$ and mannitol on peroxidase activity and lipid peroidation in Centaurea ragusina $\mathrm{L}$. roots and shoots. J. Plant Physiol., 163: 1284-1292.

Raziuddin Swati ZA, Bakht J, Farhatullah Ullah N, Shafi M, Akmal M, Hassan G. 2010. In situ assessment of morphophysiological response of wheat (Triticum aestivum L.) genotypes to drought, Pak. J. Bot., 42: 3183-3195.

Safarnejad A. 2008. Morphological and biochemical responses to osmotic stress in alfalfa (Medicago sativa L.). Pak. J. Bot., 40: 735-746.

Shafeeq S, Rahman MU, Zafar Y. 2006. Genetic variability of different wheat (Triticum aestivum L.) Genotypes/cultivars under induced water stres, Pak. J. Bot., 38: 1671-1678.

Sharma ML. 1973. Simulation of drought and its effect on germination of five pasture species. Agronomy Journal 65: 982-987.

Slama I, Ghnaya T, Hessini K, Messedi D, Savouré A, Abdelly C. 2007. Comparative study of the effects of mannitol and PEG osmotic stress on growth and solute accumulation in Sesuvium portulacastrum. Env. Exp. Bot., 61: 10-17.

Şişman EE, Gültürk P. 2011. A resaerch on primary schoolyards in terms of landscape planing and design: Tekirdağ, Journal of Tekirdag Agricultural Faculty, 8: 53-60

Thanos CA, Skordillis A. 1987. The effects of light, temperature and osmotic stress on the germination of Pinus halepensis and P.brutia seeds, Seed Science and Technology 15: 163174.

Tilki F. 2005. Seed germination and radicle development in six provenances of Pinus sylvestris L. under water stress. Israel J. Plant Sci., 53: 29-33.

Tilki F, Dirik H. 2007. Seed germination of three provenances of Pinus brutia (Ten.) as influenced by stratification, temperature and water stres, Journal of Environmental Biology, 28: 133-136.

Y1lmaz H, Y1lmaz H. 2009. The examining of usage areas of naturally growing woody plants in highway slopes: Erzurum-Uzundere case, Süleyman Demirel University Journal of Forestry Faculty A: 101-111.

Yupsanis T, Kefalas PS, Eleftheriou P, Kotinis K. 2001. RNase and DNase activities in the alfalfa and lentil grown in isoosmotic solutions of $\mathrm{NaCl}$ and mannitol. J. Plant Physiol., 158: 921-927. 